Pace University

DigitalCommons@Pace

$10-10-2010$

\title{
Returning Prosecutions to the States: A Proposal for a Criminal Justice Restoration Act
}

John A. Humbach

Elisabeth Haub School of Law at Pace University

Follow this and additional works at: https://digitalcommons.pace.edu/lawfaculty

Part of the Criminal Law Commons

\section{Recommended Citation}

Humbach, John A., "Returning Prosecutions to the States: A Proposal for a Criminal Justice Restoration Act" (2010). Pace Law Faculty Publications. 746.

https://digitalcommons.pace.edu/lawfaculty/746

This Article is brought to you for free and open access by the School of Law at DigitalCommons@Pace. It has been accepted for inclusion in Pace Law Faculty Publications by an authorized administrator of DigitalCommons@Pace. For more information, please contact dheller2@law.pace.edu. 


\title{
Returning Prosecutions to the States: A Proposal for a Criminal Justice Restoration Act
}

\author{
by John A. Humbach, Pace Law School \\ White Plains, New York \\ jhumbach@law.pace.edu
}

\begin{abstract}
A small change in the wording of an existing Federal statute could save billions of dollars in the Federal budget. Our nation's expensive and largely redundant Federal justice bureaucracy could be reduced to a fraction of its size by restoring to the states their traditional role of prosecuting crimes falling under state jurisdiction. Restoring criminal justice functions to the states could achieve a surprisingly substantial decrease in both Federal spending and the reach of Federal power.
\end{abstract}

This essay sets out and briefly analyses such a proposal.

In the past year, the calls to reduce the size of government and Federal spending seem to be growing louder and more urgent. ${ }^{1}$ Claims are made that the government in Washington has grown beyond its constitutional mandate, becoming not only a costly burden but also an increasing threat to the liberty, economic stability and the quality of American life.

While some of these claims may be debatable, it is almost certainly true that, as a historical matter, the Federal role in American governance has expanded far beyond what the Framers of the Constitution envisioned. In particular, the balance of power between the originally "sovereign" states and the national government has shifted enormously, and an ever greater concentration of power in Washington is supplanting the states' once predominant role. Instead of being a government of limited powers, the Federal government is now at the point where there seems to be little it cannot do, few kinds of laws it cannot enact, and virtually no enforceable constitutional limits on its power to tax and borrow in order to fund its ever widening range of activities.

This slow but steady evolution over the past 220 years may be for good or ill but, in the minds of a growing number of Americans, it has become a source of concern. The question is: Can anything still be done about it? The central government has already amassed a huge national debt, with obligations to pay interest, ${ }^{2}$ not to mention principal, that significantly "mortgages" our economic future to overseas creditors such as China.

\footnotetext{
${ }^{1}$ In a New York Times/CBS News poll of Tea Party backers and the general public, 50\% of the general public (and 92\% of Tea Party supporters) prefer a small Federal government spending less money on services. Polling the Tea Party (April 14, 2010), available at http:/www.nytimes.com/interactive/2010/04/14/us/politics/20100414-tea-party-poll-graphic.html\#tab=3. ${ }^{2}$ When interest rates return to more normal levels (say, $5 \%$ per annum), the cost of interest alone will be about $\$ 600$ billion per year, which would equal about $17 \%$ of 2010 Federal spending.
} 
Meanwhile, our national defense policies and commitments have fostered an international dependency on the U.S., meaning it would not be easy or, arguably, even safe for our military to withdraw or demobilize. At home our Federal public benefit programs, such as Social Security and Medicare, have already occupied so much of their respective fields that vast numbers of people not merely rely on them but generally believe, without much question, that they are essential. It is obvious, however, that if present trends continue it will not be long before virtually all governmental power on matters of significance will be centralized in Washington. For those who want to turn these trends around, the question is, therefore, how it can be done? How can the balance of governmental power be shift back toward the states without destabilizing disruptions or head-on collisions with almost irresistibly entrenched political interests?

Everyone who seeks to grapple with how to reduce the size of the Federal government is confronted with the reality that both social benefit programs and military spending are difficult to cut. However, one place where reductions in Federal size should be relatively easy is by focusing on programs that parallel or duplicate existing programs in the states. A prime example is in the field of criminal justice.

Over the last century the Federal government has taken over from the states a substantial part of the prosecutions for ordinary day-to-day violations. ${ }^{3}$ This Federal takeover has not been shown to be really necessary, but passing laws that authorize it has been a way for members of Congress to show that they are "doing something," that they deserve re-election. In the meantime, however, the states have remained fully capable of carrying out ordinary law-enforcement functions without Federal intervention and, of course, they do so every day. In fact, in the case of persons under age 18, the policy of leaving the job the states is already a part of the law. ${ }^{4}$ Congress has already prescribed that, as a general rule, no one under 18 can be prosecuted in any Federal court unless the Attorney General certifies, for example, that no "appropriate court of a State" has jurisdiction or that the state court "refuses to assume jurisdiction" over the case and that there is a "substantial Federal interest in the case or the offense."

\footnotetext{
${ }^{3}$ See infra notes 6-15.

${ }^{4} 18$ U.S.C. $\$ 5032$. The section reads, in pertinent part:

$\S 5032$. Delinquency proceedings in district court; transfer for criminal prosecution A juvenile alleged to have committed an act of juvenile delinquency, other than a violation of law committed within the special maritime and territorial jurisdiction of the United States for which the maximum authorized term of imprisonment does not exceed six months, shall not be proceeded against in any court of the United States unless the Attorney General, after investigation, certifies to the appropriate district court of the United States that (1) the juvenile court or other appropriate court of a State does not have jurisdiction or refuses to assume jurisdiction over said juvenile with respect to such alleged act of juvenile delinquency, (2) the State does not have available programs and services adequate for the needs of juveniles, or (3) the offense charged is a crime of violence that is a felony or an offense described in section 401 of the Controlled Substances Act [21 U.S.C. 841], or section 1002(a), 1003, 1005, 1009, or 1010(b)(1), (2), or (3) of the Controlled Substances Import and Export Act [21 U.S.C. 952(a), 953, 955, 959, 960(b)(1), (2), (3)], section 922(x) [18 U.S.C. $\$ 922(\mathrm{x})$ ] or section 924(b), (g), or (h) of this title [18 U.S.C. $\S 924(\mathrm{~b}),(\mathrm{g})$, or $(\mathrm{h})]$, and that there is a substantial Federal interest in the case or the offense to warrant the exercise of Federal jurisdiction.

${ }^{5} I d$.
} 
One obvious way to achieve a substantial reduction in the size and intrusiveness of the Federal establishment would be to extend this rule of Federal abstention to persons who are over 18 as well - restoring the job of ordinary criminal justice to the states. A Criminal Justice Restoration Act could achieve this reduction quite simply: All it would take is to remove the age limit from the existing law for juvenile cases and clarify that the required Federal interest be a uniquely Federal interest, i.e., one that is reserved to the Federal government under the United States Constitution. This small legislative change, a few words in a single section of the United States Code, could make a major inroad in the degree to which Federal power holds sway within the states, and it would be an major step in the direction of reducing the Federal government to a more constitutionally appropriate size

The Federalization of Ordinary Criminal Justice. In some federated nations, such as Canada, the criminal law is almost totally a matter of federal law, and the national constitution gives the provinces or states only limited jurisdiction over crime. In the United States, however, there is a long and strong traditional of treating public safety and criminal redress primarily as matters of state responsibility. In America, criminal law has, until fairly recently, been almost exclusively state law.

Over the decades, however, especially in the last half-century, the government in Washington has increasingly taken it upon itself to prosecute and punish ordinary crimes. In the process, it has built up a parallel criminal justice bureaucracy whose function and operations largely duplicate what already exists in the states. As a result, the Federal government now holds more than 180,000 people in its prisons, ${ }^{6}$ representing an increase of nearly $30 \%$ over the year 2000 , with an average increase of $4.5 \%$ per year. These Federal prisoners are mostly held for acts that traditionally were already crimes under state law:

\begin{tabular}{lc} 
Crime & Prisoners $^{7}$ \\
\hline Homicide & 2949 \\
Robbery & 8718 \\
Other violent crime & 3817 \\
Burglary & 475 \\
Fraud & 7728 \\
Other property crimes & 2876 \\
Drug crimes & 95079 \\
Gun ownership crimes, etc. & 26928 \\
Sex crimes, etc. & 12678
\end{tabular}

Of the total Federal prisoners, only those convicted of immigration offenses $\left(19,678^{8}\right)$ and a small number of others (listed as "other/unspecified" offenses) ${ }^{9}$ fall within the Federal government's exclusive constitutional jurisdiction. Virtually all of the rest of

\footnotetext{
${ }^{6}$ William J. Sabol, Heather C. West \& Matthew Cooper, Prisoners IN 2008, Bureau of Justice Statistics Bulletin, U.S. Department of Justice 38 (December, 2009)(reporting 182,333 persons held in 2008).

${ }^{7} I d$. (2008 figures).

${ }^{8} \mathrm{Id}$.

${ }^{9} I d$. The total held for "other/unspecified" offenses is 1,394.
} 
come under Federal authority, not because of any unique constitutional interest or nexus, but solely because the Supreme Court's broad reading the commerce power allows the Federal government to selectively pre-empt traditional state control.

Federal involvement in ordinary law enforcement, pursuing conduct that has no uniquely Federal nexus, seems if anything to be growing. During the decade between 1997 and 2006, Federal criminal prosecutions rose $34 \%{ }^{10}$ despite the fact that the nation's crime rate has been falling. But this Federal takeover of historically state jurisdiction does not come cheap. The U.S. Department of Justice currently spends around $\$ 25$ billion per year, of which around $\$ 15$ billion goes for law enforcement ${ }^{11}$ and nearly $\$ 7$ billion to feed, house and secure the Federal government prisoners ${ }^{12}$ in 115 Federal prisons around the country. ${ }^{13}$ On top of this, operating the Federal court system costs another $\$ 7$ billion per year, ${ }^{14}$ the bulk of which is accounted for by criminal prosecutions and appeals. Added all together, this Federal criminal-justice activity is increasing the Federal deficit by close to $\$ 30$ billion per year - or about $\$ 100$ for every man, woman and child in the country. This may not seem like much, but these expenditures will, if allowed to continue, add nearly half a trillion dollars to the national debt in just the next 12 years. ${ }^{15}$

Does the Federalization of Criminal Justice Make Sense? Whether the taxpayers are receiving value for all this money spent on Federal justice is debatable. On one hand, the Federal government's parallel criminal-justice bureaucracy provides an additional a layer of government regulation and control that can supplement and, if necessary, backstop traditional state enforcement. If a state response is ineffective, the government in Washington can step in and pick up the slack. While this backup capacity has been of definite importance in dealing with the nation's historically special problems in the area of civil rights, it is not so clear that it is otherwise indispensable. On the other hand, it is not obvious that always having an extra layer of government power and control is good thing. That seems, for example, to be the core message of the "Tea Party" movement and other constitutional conservatives who believe the Federal government has grown too large.

The Federal prosecution establishment is an important vehicle for projecting Federal power into the states and in every corner of the nation. It is the primary means for making sure that the force of Federal power is felt, even on traditionally non-Federal issues, across the 50 states. Presumably, the way one feels about this pervasive projection of Federal power depends how one feels about Federal power generally.

\footnotetext{
${ }^{10} \mathrm{http}: / /$ www.uscourts.gov/ttb/2007-11/decade/index.html

${ }^{11} 2010$ Budget Summary and 2010 Budget Request by Strategic Goal (U.S. Department of Justice), available at http://www.justice.gov/jmd/2010summary/pdf/bud-summary.pdf (last visited March 8, 2010).

${ }^{12}$ Summary Budget of Federal Prisons System (BOP), available at http://www.justice.gov/jmd/2011summary/pdf/fy11-bop-bud-summary.pdf (last visited March 8, 2010). Other "administration of justice" programs cost an added \$2-3 billion per year. See 2010 Budget Summary and 2010 Budget Request by Strategic Goal (U.S. Department of Justice), available at http://www.justice.gov/jmd/2010summary/pdf/bud-summary.pdf (last visited March 8, 2010).

${ }^{13} \mathrm{Id}$.

${ }^{14}$ Judiciary Budget: FactS AND ImPaCt, available at http://www.uscourts.gov/budget.html (last visited March $8,2010)$

${ }^{15}$ Assuming that the budgeted amounts continue to increase at about $3.5 \%$ per year.
} 
Under the view prevailing in recent decades, a strong nation requires a strong national government, and the concentration of increasing power in Washington is exactly what the country should be doing. On the other hand, under what might be called the "constitutional conservative" view, state government is the level of government that should have primary relevance to people's day-to-day lives. Even though Washington has shaken off most of the formal limits on its power in the years since Wickard v. Filburn, ${ }^{16}$ the argument goes, that does not mean it should take any power that it can. The mere fact that the Federal government legally can override the authority of the states does not mean that it should.

As mentioned earlier, all the current Federal criminal-justice activity is increasing the national deficit by close to $\$ 30$ billion per year. ${ }^{17}$ Of course, turning prosecutions and punishment back over to the states does not mean their costs would entirely disappear. At the same time, however, it is almost certain that having two large and overlapping sets of bureaucracies, as we currently do, costs us far more than having only one. And there is every reason to think that the states could absorb the additional cases without budgetary burden. Returning criminal justice to the states would, on average, add only 2-3 cases (mostly plea bargains) to the monthly caseload per county.

By contrast, as things now stand every state has, not merely its own criminaljustice apparatus, but also one or more fully staffed U.S. Attorney's offices. Each of the Federal operations is, in effect, a large law office with its own management costs, its own separate facilities and its own separate overhead expenses. Whatever the exact cost of all this duplication, it is a cost that is probably too much at a time when every additional dollar of Federal spending has to be, in effect, borrowed overseas. Indeed, duplicating government functions seems be the very paradigm of "waste and abuse."

Even apart from cost, however, there are constitutional policy concerns that may cause us to question whether having two duplicative prosecution authorities is really good for liberty. The traditional constitutional ideal of centering most governmental power in the states, not in Washington, has already been mentioned, but there are other concerns as well. For example, removing duplicative Federal prosecution capacity would eliminate most of the potential for "double jeopardy" that currently exists. Nowadays, both the state and Federal authorities can prosecute an accused for one and the same act-something that goes against the spirit if not the letter of the Double Jeopardy Clause. Then there is the somewhat uncomfortable fact that many Federal prosecutions, an estimated $18 \%$ in 2006, are secret, shielded from public view. ${ }^{18}$ Beyond that, Federal prosecution power can be (and has been) used anti-democratically for the express purpose of defeating freedoms established by the states. ${ }^{19}$

\footnotetext{
${ }^{16} 317$ U.S. 111 (1942) (greatly increasing the Federal power to make laws under the Commerce Clause).

${ }^{17}$ See supra note 15.

${ }^{18}$ Molly McDonough, 18 Percent of Federal Criminal Cases There Are Shielded From Public, Study Says, 5 ABA Journal eReport 10 (March 10, 2006),

${ }^{19}$ For example, Gonzales v. Raich, 545 U.S. 1 (2005) (upholding the Federal power to convict and imprison persons growing and using marijuana, as expressing permitted under otherwise valid state laws).
} 
Finally, and perhaps most significantly, the very existence of a large and versatile Federal prosecution force supplies a natural temptation to adopt ever new kinds of Federal laws of the kind that have, over time, radically expanded the power and reach of the Federal government. Many of these laws are supposed to deal with so-called "national" problems. Often, however, the "national" problem turns out to be, in reality, just another ordinary state-level problem that happens to be shared by a number of states. Since nearly every substantial challenge that a state faces is likely also to be faced by other states as well, there is a constant supply of so-called "national" issues, and they provide a fertile source for the continuing extensions of Federal power, expanding it into every corner of the nation's life. If the Federal government adopted a policy not to prosecute cases within the traditionally state purview, it would take away an incentive (or, at least, make it less easy) for the Federal government to use its "commerce" power to intrude on the state's historical domain.

Drawing the Line on Federal Prosecutions. As stated earlier, an obvious way to reduce the size and intrusiveness of the Federal establishment would be to extend the rule of Federal abstention in criminal justice to cases involving persons over 18 and to stop the use of Federal funds for prosecutions do not involve uniquely Federal interests under the Constitution. This small change of only a few words in the United States Code would withdraw the Federal government from the business of launching prosecutions for conduct that the Constitution does not place in exclusively national jurisdiction (such as tariff enforcement) or acts that directly harm or impede the constitutional functioning of the Federal government itself (for example, assaults on Federal officers, trespasses on Federal property or treason). All ordinary crimes, from homicide to drug offenses, would be left to the states. The states' full traditional criminal justice power would be restored.

Assuming that it is decided to restore most criminal-justice authority to the states, where should the line be drawn? What should count as a uniquely Federal nexus that would justify prosecution and punishment at the Federal level rather than by the states?

Today, the Federal government exercises criminal justice jurisdiction under laws that fall in several different categories. One category consists of laws enacted to carry out and support powers that the Constitution delegates exclusively to the Federal level of government, for example laws pertaining to national security and border protection, the post office or the mint. Another category consist of laws that are needed to regulate matters as to which the states are constitutionally disempowered, for example laws to prevent the imposition of discriminatory burdens on interstate commerce. And still another category consists of laws designed to achieve results which, though necessary or desirable, the individual states simply cannot achieve on their own-for example, to protect interstate resources or to control interstate pollution. With respect to laws in these three categories, it is logical that any criminal sanctions be sought and imposed by the Federal government itself: Particularly within the exclusive sphere of its own constitutional mandate, the Federal government should not have to depend on others.

There are, however, many other Federal laws that are either partially or totally redundant with state laws - or with laws that states could have enacted but did not 
because they opted for liberty instead. As already shown in the chart set out earlier, ${ }^{20}$ laws in this "redundant" category account for the vast majority of Federal criminal justice activity. To the extent that these laws are fully redundant with already existing state laws, they serve no obvious purpose at all-except to expand the reach of Federal power. When Federal laws cover matters that the states have opted not to regulate, the situation is even worse. Such laws seem to represent a flat-out Federal intrusion on the state's choice not to impose particular limits on their citizens' liberty, to leave their citizens in peace. $^{21}$

Oftentimes the redundant laws are enacted with good intentions, for example to provide Federal support for the state policies whose enforcement might tend to be frustrated due to the interstate nature of a problem. A classic example is the National Motor Vehicle Theft Act. ${ }^{22}$ The invention of the automobile resulted in a new class of mobile assets that were highly attractive to thieves. It was apparently an easy matter for car thieves to escape detection by driving stolen cars across state lines. The states had laws punishing car theft, of course, but the law enforcement authorities inside each state were hobbled by the territorial limits on their authority. The cars' mobility simply outran them. By prohibiting interstate transportation of stolen vehicles, the National Motor Vehicle Theft Act gave the national police (viz. the F.B.I.) the legal power to investigate interstate car thefts and apprehend the thieves.

Clearly, problems of the kind that motivated the National Motor Vehicle Theft Act are still with us today, but the precise solution provided by that Act, a new Federal crime, was not necessary then nor is such a solution necessary now. While having a national police force is valuable for resolving interstate crimes, it does not follow that we also need to have a national bureaucracy to carry out the prosecutions or punishments. In the case of car theft, for example, once the thieves are apprehended by a national agency such as the F.B.I., the Federal government's necessary role is over. At that point the state where the crime occurred has just as much legal capability (and rightful claim) to prosecute the wrongdoer as a Washington-based bureaucracy. Federal investigation agencies are obviously valuable, but in a true "federal" democracy the involvement of such agencies would be at the request and in the service of the states, not as a superimposition on them. That is, at least, consistent with the constitutional plan envisioned by the Founders.

There is certainly no practical reason why, in the name of strengthening our decentralized federal system, agencies like the F.B.I. cannot provide law-enforcement assistance without the further step of federally preempting the prosecution and punishment as well. Indeed, the F.B.I.'s crime laboratory already provides an excellent example. It represents a valuable forensic service that the government in Washington

\footnotetext{
${ }^{20}$ See supra text accompanying notes 6-15.

${ }^{21}$ Note that I would distinguish in this discussion those Federal laws passed pursuant to constitutional provisions such as the 14th and 15th amendment which (unlike, say, the Commerce Clause) were specifically motivated by a purpose to rein in certain kinds of evils considered tolerable by certain of the states but intolerable by the nation as a whole.

2218 U.S.C.A. § 408. See McBoyle v. United States, 283 U.S. 35 (1931).
} 
provides to the states without, in the process, supplanting them. It is a model that is true to the Constitution's intent.

Conclusion. In sum, the Constitution was not intended to focus governmental power in the central government while the states gradually atrophy away. The individual states, some of which are larger than most countries, are fully capable of handling their own systems for criminal justice. This fact certainly raises the question, at least: Do we really need the ongoing Federal takeover of prosecutions? Yet, based on present trends, a Federal takeover of large portions of the American justice system continues almost unquestioned. But is the continuation of present trends an inevitable progression?

If the trend is not inevitable, then enactment by Congress of a Criminal Justice Restoration Act, returning ordinary criminal justice functions to the states, would be a significant step in reversing the accumulation of power in Washington. All that is needed is to change a few words in one section of the United States Code, extending the existing Federal abstention in juvenile cases to all criminal cases. No large Federal program is as easy to turn back over to the states as the prosecution of crimes that fall within the states' traditional purview. 